\title{
Some of the Contents of Higher Education Service Development in Vietnam
}

Bui Thi Van*

University of Transport and Communications, No.3 Cau Giay Street, Lang Thuong Ward, Dong Da District, Hanoi, Vietnam

\section{*Corresponding Author}

Bui Thi Van

\section{Article History}

Received: 19.09 .2020

Accepted: 27.09.2020

Published: 02.10.2020

\begin{abstract}
The development of higher education in Vietnam in the period of accelerating industrialization, modernization, and deeper integration into the world economy is of great concern to the whole society. Policies and policies to socialize public services, including educational services, have been promulgated by the Party and the State since the "Innovation" (1986), especially the autonomy regulation awarded to a number of universities since 2005 aims to facilitate the development of higher education service delivery. However, up to now the higher education system in Vietnam is still developing at a low level, slowly being improved. The article mentions higher education services, overview policies, the current situation of higher education service delivery in Vietnam, and gives some recommendations.
\end{abstract}

Keywords: Contents, higher education, service development, universities, Vietnam.

\section{INTRODUCTION}

Education is the process of acquiring and acquiring knowledge, skills, values, beliefs and habits of a person or a group of people through teaching - learning or research activities. Formal education is usually organized through the school system and is divided into stages. Higher education is a high-level education level for those who have graduated from high school in order to provide highly qualified human resources for the economy, including universities and institutes (hereinafter referred to as general is university).

Previously, in Vietnam, higher education was seen as a pure public good. Currently, many modern economists believe that higher education is more of a private good in nature because it mainly benefits the learners $[1,2]$.

In fact, the service of higher education is a special service that is both public and self-interested. The common good is manifested in the benefits that a nation and human society derive from highly educated people such as an increase in high quality human resources; social evils and crimes have been reduced. Self-interest is shown in specific benefits for learners such as having a university or higher education, learners will have more opportunities for income, better life and personal development.

Therefore, students need to pay most of the costs for college education. Higher education services are a special commodity that the private sector can engage in. From there, create an environment of equal competition for all universities, whether public or private, operating for profit or not for profit. The demand for university education tends to increase and is increasingly diversified, while the limited supply from the state is increasing the participation of private investors. Currently, higher education services are provided by the majority of countries and have become a global business sector.

This type of service also requires the provision and intervention from the state for many reasons such as: this is a recommended commodity and for the purpose of social equity, creating opportunities to access education services for all people, the State needs intervention, it brings common benefits to the whole society, spread knowledge and promotes

Copyright @ 2020: This is an open-access article distributed under the terms of the Creative Commons Attribution license which permits unrestricted use, distribution, and reproduction in any medium for non commercial use (NonCommercial, or CC-BY-NC) provided the original author and source are credited. 
social progress [3]. Development trends in countries today, the state plays an important role in creating an autonomous university environment in order to meet the need for high-quality human resources for socio-economic development and overcoming of shortcomings of the higher education service delivery market.

In modern societies, universities perform the main functions of creating knowledge, imparting knowledge and disseminating knowledge. In which, knowledge creation associated with research activities, knowledge transmission associated with education and training activities, knowledge spread associated with knowledge transfer activities to agencies such as joint industry, communication.

The services provided by the university are very wide, including: (1) Main services such as providing undergraduate and graduate courses; (2) Other educational services such as training packages for businesses, fostering knowledge, short-term programs, etc; (3) Technical services, consulting; (4) Services related to the material and cultural life of the student; (5) University operation services such as security services, machine maintenance and repair, school management services. In which, the main service of higher education is the main education courses at undergraduate and graduate level.

In the scope of this article, the service of higher education is the service of imparting specialized knowledge ie educational - training activities. The output products are graduates at all levels of degrees such as bachelor, engineer, master and doctor.

\section{LiTERATURE REVIEW}

Higher education services have characteristics such as the quality of the service which is difficult to determine, the output quality is not shown at the end of the supply process but after a while. University is the provider; the student is the consumer - the demand for higher education services. These are the two main subjects, in addition there are a number of other related subjects such as: Student's family is the financial provider; Lecturers are those who transmit knowledge on behalf of the school; Government finances and performs the role of state administration; Credit rating and rating organization is an independent agency that evaluates the quality of educational services of universities based on the set of criteria.

The process of providing higher education services is reflected in the university-student interaction in three main phases: enrollment, training and the post-graduation period. Today, people in different countries can go to different universities to study with very diverse professional, cultural or social capital needs. The diversity of university needs leads to diversification of types of universities.

Based on the purpose of operation, the university is divided into research-oriented, application-oriented and practice-oriented universities. Based on form of ownership, including public and private universities. A public university is a state-owned university that invests in and builds facilities and ensures the conditions for operation in accordance with law. Private university means a school owned by social organizations, private economic organizations or individuals (investors), invested by these organizations and individuals, and built facilities and ensure operating conditions as prescribed by law.

Higher education services are provided by public universities, private for-profit universities and non-profit universities. The competitive nature in the higher education field has many characteristics. Universities compete with each other to attract students to study, especially excellent students through reputation and prestige; through the price that is the tuition fees that students have to pay; etc.

Due to the strong development of the higher education sector, countries around the world now tend to increase autonomy for universities, including public universities to increase competition. The degree of autonomy of the university reflects the relationship between the state and the university. Accordingly, it can be divided into: Universities fully controlled by the state and highly subsidized; Universities are partly autonomous, the state still intervenes in some stages; Independent, fully autonomous universities, with no direct intervention from the state.

\section{An Overview of the Current Situation of Higher Education Service Provision in Vietnam}

Regarding the legal framework for higher education development:

Along with the renovation and opening of the economy, the higher education sector in our country has been gradually reformed in the direction of allowing all economic sectors to participate in the provision of higher education services. Development of higher education to develop human resources has become an urgent requirement in the process of industrialization and modernization of the country. Immediately after the "Innovation" in 1986, Vietnam encouraged private sector to participate in the higher education service delivery sector. In fact, the Thang Long Private University 
Center was established in 1988 and five years after its pilot operation, more than 10 non-public universities were established.

The policy of developing higher education, reforming management is shown in the Education Law 1998 [4]. The law mentions the autonomy of institutions of higher education. Accordingly, higher education institutions are given autonomy in a number of contents such as: building programs, textbooks, teaching and learning plans; organize enrollment, organize the training process; organization of the school apparatus; cooperation with economic, educational and cultural organizations.b bb Thus, legally, higher education institutions in our country are given quite high autonomy. This is a great step forward in the higher education development policy in our country.

However, the exercise of autonomy must comply with the law and the School Charter. Specifically, until 2002, there was a decree on financial regimes applicable to non-business units with revenues, guiding the financial autonomy of these units, including higher education institutions (Decree No. 10/2002/ND-CP dated January 16, 2002) [5]. In 2003, the University Charter was issued. Due to the delay in promulgation of legal documents and many other reasons, the policy on university autonomy has not been implemented for many years in our country. The transition in higher education management from centralized management during the subsidy period to a model of university autonomy has been very slow.

The Law on Education 2005 [6] marks an important step in the realization of higher education institutions' autonomy. Due to legal overlaps, specific regulations, also known as "sub-licenses", prolong the application mechanism, so the mechanism of autonomy and self-responsibility for higher education institutions has not been fully implemented and is asynchronous.

The legal framework for private universities has also been gradually completed. Resolution No. 05/2005/NQ-CP dated 18/4/2005 of the Government on promoting socialization of education, health, culture and sport activities [7]. This is an important document in the development orientation of non-public higher education from 2005 up to now. In 2006 , Vietnam became the 150th member of the WTO, committing to open education as a service sector. This clearly shows the State's view of educational development that not all countries can do. In 2009, Vietnam allowed the establishment of $100 \%$ foreign-owned higher education institutions.

The Law on Higher Education in 2012 marked a strong innovation in higher education development [8]. Accordingly, the state only manages the macro, develops and completes the system of policies for higher education development, higher education institutions are given autonomy in activities mainly in the organizational fields, human resources, finance and assets, training, science and technology, international cooperation and higher education quality assurance. The Law on Higher Education 2012 was born, aiming to socialize higher education, giving priority to the establishment of private higher investment institutions with large capital investment, and encouraging higher education institutions. Foreign-invested private and higher education institutions operate not for profit [8].

On August 9, 2012, the Government issued a resolution on the Government's Action Program to implement the announcement of the Politburo's Conclusion on the Project "Renovating the operation mechanism of public non-business units, promoting to socialize some types of public non-business services" (Resolution No. 40 / NQ-CP) [9]. Concretizing the spirit of Resolution No. 40 in the higher education field, the Government issued Resolution No. 77/NQ-CP dated October 24, 2014 on pilot reform of operating mechanisms for Public higher education department for the period 2014 2017. Accordingly, public higher education institutions, when committing to self-guarantee for all operating expenses, their recurrent and investment expenditures, are made autonomous and fully accountable [10]. As of 2018, the whole country has 23 public universities participating in the pilot implementation under Resolution No. 77.

This is an important step in renovating the thinking of management of public services, a breakthrough in the innovation of higher education administration. The role of the State has shifted from command and control to empowering and supervising on a basis The State still provides and finance higher education to ensure higher education is fundamentally public interest.

However, in practice, the operation of public universities in general, autonomous pilot schools and non-public universities still do not achieve the goals such as the reform policy. The implementation progress of autonomy of public universities is very slow; the picture of higher education in our country over the past time shows embarrassment in state management. Law No. 34/2018/QH14 dated November 19, 2018, effective from July 1, 2019, amending and supplementing a number of articles of the Law on Higher Education. In the spirit of the Law, higher education institutions exercise autonomy to a higher degree. 


\section{Overview of the higher education situation in Vietnam}

According to statistics from the Ministry of Education and Training, as of 2019, the whole country has 237 universities, including 172 public schools (accounting for about 72.5\%) and 65 non-public schools (accounting for about $27.5 \%$ ). In which, there are 5 schools with $100 \%$ foreign investment [11].

In the academic year 2018 - 2019, nationwide, the proportion of learners in the public university sector: university students accounted for $82.7 \%$, graduate students accounted for $87.2 \%$, graduate students accounted for $97,8 \%$. The remainder belongs to the non-public sector (Table 1) [11].

The proportion of non-public university students accounts for $17.3 \%$, this is quite a modest rate. Around the world, often in the least developed countries or some very developed countries where the state budget funds almost all the costs of education at new levels have a low proportion of the number of students, the number of non-public schools creates. Currently, Vietnam has reached the middle income threshold, is an open, dynamic economy, in 2006 joined the WTO, and committed to open the education sector as a service sector but until now the education system Vietnamese universities are still heavy on public.

Table-1: General data Higher Education in Vietnam

\begin{tabular}{|c|c|c|c|c|c|c|}
\hline \multirow[t]{2}{*}{ Criteria } & \multicolumn{3}{|c|}{ 2017-2018 } & \multicolumn{3}{|c|}{ 2018-2019 } \\
\hline & Total & Public & Out of public & Total & Public & $\begin{array}{l}\text { Out of } \\
\text { public }\end{array}$ \\
\hline $\begin{array}{l}\text { Number of } \\
\text { universsities }\end{array}$ & 236 & 171 & 65 & 237 & 172 & 65 \\
\hline $\begin{array}{l}\text { Number of new } \\
\text { university students } \\
\text { recruited }\end{array}$ & 437.156 & 352.982 & 84.174 & 413.277 & 324.707 & 88.570 \\
\hline Formal & 368.843 & 290.300 & 78.543 & 360.140 & 275.961 & 84.179 \\
\hline $\begin{array}{l}\text { Workingwhile } \\
\text { studying }\end{array}$ & 54.613 & 49.895 & 4.718 & 39.381 & 35.986 & 3.395 \\
\hline Distance training & 13.700 & 12.787 & 913 & 13.756 & 12.760 & 996 \\
\hline $\begin{array}{l}\text { New recruiting } \\
\text { masters and } \\
\text { doctors } \\
\text { Graduate students } \\
\text { Postgraduate }\end{array}$ & $\begin{array}{l}48.106 \\
45.032\end{array}$ & $\begin{array}{l}\mathbf{4 1 . 9 0 8} \\
39.269\end{array}$ & $\begin{array}{l}6.198 \\
5.763\end{array}$ & $\begin{array}{l}\mathbf{4 3 . 6 5 6} \\
42.160\end{array}$ & $\begin{array}{l}37.519 \\
36.237\end{array}$ & $\begin{array}{l}\mathbf{6 . 1 3 7} \\
5.923\end{array}$ \\
\hline College student size & 1.707 .025 & 1.439 .495 & 267.530 & 1.526 .111 & 1.261 .529 & 264.582 \\
\hline $\begin{array}{l}\text { Scale of masters } \\
\text { and doctoral } \\
\text { training } \\
\text { Graduate students } \\
\text { Postgraduate }\end{array}$ & $\begin{array}{r}106.567 \\
14.686\end{array}$ & $\begin{array}{l}92.586 \\
14.397\end{array}$ & $\begin{array}{c}13.981 \\
289\end{array}$ & $\begin{array}{l}97.134 \\
11.000\end{array}$ & $\begin{array}{l}84.706 \\
10.758\end{array}$ & $\begin{array}{c}12.428 \\
242\end{array}$ \\
\hline College graduates & 341.633 & 302.677 & 38.956 & 311.599 & 266.970 & 44.629 \\
\hline $\begin{array}{l}\text { Faculty members } \\
\text { Professor }\end{array}$ & 74.991 & 59.232 & 15.759 & 73.312 & 56.985 & 16.327 \\
\hline Associate professor & 729 & 529 & 200 & 519 & 379 & 140 \\
\hline $\begin{array}{l}\text { Divide by level: } \\
\text { Doctor }\end{array}$ & 4.538 & 3.796 & 742 & 4.139 & 3.525 & 614 \\
\hline Masters & 20.198 & 17.003 & 3.195 & 21.106 & 17.336 & 3.770 \\
\hline University & 45.266 & 36.224 & 9.042 & 44.705 & 35.123 & 9.582 \\
\hline Other level & $\begin{array}{c}9.495 \\
32\end{array}$ & $\begin{array}{c}5.989 \\
16\end{array}$ & $\begin{array}{l}3.506 \\
16\end{array}$ & $\begin{array}{c}7.489 \\
12\end{array}$ & $\begin{array}{c}4.516 \\
10\end{array}$ & 2.973 \\
\hline
\end{tabular}

Source: Ministry of Education and Training (schools and students do not include security and defense sector)

\section{General Assessment of Higher Education Service Delivery in Vietnam and the Problems Raised}

In recent years, Vietnam's higher education has made certain strides towards autonomy, enhanced accreditation, and publicity of the quality of education. In 2020, Vietnam has 3 higher education institutions listed in the list of 1000 top universities in the world according to the most prestigious international rankings. To date, there are more than 160 higher education institutions and more than 300 training programs in Vietnam that have been accredited by prestigious 
domestic and international accreditation organizations. Higher education institutions initially have innovations in the direction of self-control, accessing to management tools to identify their capabilities [11].

However, the quality of Vietnamese universities is currently a big problem. Higher education is still inadequate [11]. Programs and textbooks have not been standardized, and have not yet met the requirements of the labor market. The quality of the laboratory and facilities is still poor due to the lack of investment funds and insufficient libraries and documents for students [12, 13]. Many universities, especially non-public schools, do not have sufficient conditions for construction land to meet the standards of university land fund at $2.5-3 \mathrm{~m} 2 / 1 \mathrm{sv}$ [11] .

Organic faculty with a PhD or higher are relatively low. In the academic year 2018-2019, the number of organic lecturers of universities in our country is 73,312, of which 21,106 (accounting for 28.7\%) for doctoral degrees, 44,705 for masters $(60.9 \%)$ ), the rest are university degrees. The number of professors and associate professors is 4,658 , accounting for $6.3 \%$ [11]. For many non-public schools, much dependence on hiring lecturers from public schools, so there are still many passages.

Vietnamese university degrees are not recognized by the world for quality, students find it difficult to participate in exchange programs with universities in the world or transfer to study at national universities practice. The fact that our country provides higher education services at a very low cost compared to the world (training costs for 4 years in Vietnam are only approximately equal to 1 semester of the world average) is also one of the the reasons for the low quality of higher education output [12].

Many universities do not really attach importance to quality accreditation [13]. Although the set of standards for evaluating university quality with 61 criteria, 10 standards related to all activities of universities were issued by the Ministry of Education and Training in 2007 and have been implemented since However, by the end of the 20172018 school year, there were only 5 schools that were independently accredited and more than 200 schools completed the selfaccreditation. From the school year of 2018-2019, a new set of criteria has been issued to suit the new context under the strong impact of the industrial revolution 4.0 and so far there are no statistics on the performance results this new lice.

\section{In that context, there are a number of issues raised, specifically \\ Regarding the competitive environment between the public and private sectors}

Although the Government has made efforts to encourage the private sector to participate in the provision of higher education services, there is still an inequality between public and non-public schools. Students in public schools may receive incentives from the government, but students at non-public schools cannot. Some non-public schools lower enrollment benchmarks, recruiting more students than their ability to train, regardless of the number, quality of faculty members, and facilities. This is unfair competition from some private schools. Even in the Higher Education Law 2018, there is still a section on public universities and private universities [14], which means there is still unfair discrimination between types of training.

\section{About university autonomy}

The legal corridor for autonomy is not clear; policy mechanisms are not uniform, still have many shortcomings. There are still many regulations and documents guiding the implementation of autonomy, which have been issued slowly and have not created conditions for schools to exercise autonomy.

The awareness of lecturers in public schools and students on the issue of autonomy is not sufficient. Many important issues about autonomy have not been clarified in universities such as the relationship between the Rector Board and the School Council and Party Committee; have not specified specific employment positions of lecturers; has not yet developed a mechanism for salary and additional income under the financial autonomy mechanism. With schools that are autonomously implemented under the pilot regulations, due to limited revenues, they face many difficulties in spending, accumulating, building facilities, and attracting quality lecturers.

Currently, state management agencies have not really created conditions for universities to exercise autonomy. The private participation in the higher education sector is still modest, reflected through investment capital, ownership structure, and revenue from socialization. Most of the private schools over the past time only train in the "hot" industries and excessively expand the training scale compared to the ability of the school to supply.

The role of the state's macro management in order to overcome the shortcomings of the market that has not done well, has not managed the quality of output, for example, in industries with high market demand has been overly expanded without taking into account supply capacity of the school as well as the excess number of student output compared to social needs. 


\section{Some Policy Recommendations to Develop Higher Education in Terms Of Higher Autonomy in Vietnam}

Create a healthy and equal competitive environment in the higher education system. In order to create an environment of free competition and equality between public and private schools in order to develop higher education services, there should only be provisions in the legal documents that state-invested public schools and private schools. Invested by non-state actors, the other contents are regulated equally.

Renew the thinking, management and supervision mechanism of state management agencies for higher education. The basic function of state management is development orientation, establishment of a legal framework, implementation of law enforcement inspection and supervision, and a healthy competitive environment in the field. University education. Improve university governance capacity both at the macro and micro level, and expand and improve the efficiency of university autonomy.

Mechanisms, policies, laws and legal documents need to be revised fastest. Although the Higher Education Law has been revised, the guiding documents need to be revised in order to create a good legal corridor for schools to develop under the Party's major policy. Autonomy of the university is not given to any individual, but to the entire university, including lecturers, staff, and students, which the University Council represents.

The State does not interfere too deeply in the professional affairs of universities. It is necessary to accelerate the process of giving autonomy to universities. The State should only focus on a number of stages, areas such as program quality moderation, lecturers, facilities and the quality of the output of learners. To do so, it is necessary to improve the capacity of the institution, the apparatus and personnel of the state sector. Expanding autonomy requires synchronous innovation in all stages, creating conditions for schools to compete equally to improve the quality of education and training.

Reforming the financial mechanisms for the university system should focus on promoting socialization to attract investment in the whole society and reforming the budget allocation mechanism for each school and student group. . Gradually shifting from direct support to schools to scholarships, student credit and scientific research funding. It is necessary to develop basic criteria for the allocation on the basis of encouraging schools to have an incentive to improve the quality of training and research, regardless of public or private schools. Based on the level of the quality of training and research criteria that the schools achieve to allocate the budget.

The State needs to build a financial mechanism to provide funding for universities in the form of competition, according to capacity to achieve the highest efficiency. Except for some schools, some special branches meet the longterm requirements of society where the state needs to provide funding under a special mechanism (this is the role of the state to intervene to minimize the shortcomings. of the market, such as focusing on training according to the short-term needs of the market, underestimating industries with long-term benefits to society). On the other hand, the policy support for research investment, research infrastructure should be based on the actual performance, the school that does well will be provided with more funding.

Policies to support research funding associated with graduate training and scholarship policies for graduate students. Policy on greater autonomy in topic funding as well as research programs.

The State creates a favorable mechanism for domestic universities to cooperate with major universities in other countries on joint training programs or under different modes of cooperation. Thereby, helping the universities in our country to access advanced training programs, curriculum, and management skills. At the same time, students have access to effective learning methods, with international curriculum and learning knowledge.

The State should give autonomy to schools to build recruitment mechanisms and pay salaries and bonuses for teachers. Lifetime staffing should be abolished in public universities.

Clear views on students' place in the higher education services market. Expand options and improve student financial aid effectiveness. Expanding options for students to switch schools and branches. The state supports, grants scholarships, and credit for students, regardless of public or private schools. Create a convenient mechanism for students to evaluate the quality of teachers, curriculum and curriculum and see this as an independent party in the evaluation.

\section{CONCLUSION}

Expanding autonomy needs to go hand in hand with the quality rating and rating system for universities. The State needs a mechanism to promote schools to participate in quality accreditation and rating by independent rating agencies. Regulations are needed to ensure that accreditation is truly objective and fair by adopting an effective and appropriate set of quality management tools to "compare" the quality assurance indicators between schools. University. 
Thereby, universities can use the criteria and indicators to self-evaluate the results of their activities, and at the same time use them as a tool for strategic management and brand development. Learners will have accurate information about the universities so that they can choose schools, fields and careers in accordance with their own capabilities and strengths.

The above fact raises the requirement to continue to socialize public services in the education sector in a reasonable way to ensure development orientation and to encourage, promote and improve the quality of socialization public services in the education sector. This is both a requirement and a condition to really promote the role and driving force of socialization in the innovation process, exploit the intellectual and material potentials of the people, and mobilize the whole society to take care of education career; at the same time, creating conditions for the entire society, especially policy beneficiaries and the poor, to enjoy educational achievements at an increasingly high level.

\section{ACKNOWLEDGMENT} MLN-006.

This research is funded by University of Transport and Communications (UTC) under the project code T2020-

\section{REFERENCES}

1. Milton, F. (1962). Capitalism and Freedom. London \& Boston: Nicholas Brealey.

2. Gary, B. (1974). A theory of social interactions. Journal of Political Economy, 82(6), 1063-1093.

3. John, S. Mill. (2011). Socialism. Chicago: Belfords, Clarke \& Co. Mdccclxxix.

4. National Assembly of the Socialist Republic of Vietnam. (1998). Education law.

5. Government of the Socialist Republic of Vietnam. (2002). The Decree on financial regimes applicable to nonbusiness units with income, guides the financial autonomy of these units including higher education institutions.

6. National Assembly of the Socialist Republic of Vietnam. (2005). Education law.

7. Government of the Socialist Republic of Vietnam. (2005). To step up the socialization of educational, medical, cultural and sport activities.

8. National Assembly of the Socialist Republic of Vietnam. (2012). The Law on Higher Education.

9. Government of the Socialist Republic of Vietnam. (2012). Resolution on the Government's Action Program to implement the announcement of the Politburo's Conclusion on the Project "Renovating the operation mechanism of public non-business units, promoting to socialize some types of public non-business services".

10. Government of the Socialist Republic of Vietnam. (2014). Resolution No. 40 in the higher education field, the Government issued Resolution No. 77/NQ-CP on pilot reform of operating mechanisms for Public higher education department for the period 2014-2017.

11. Ministry of Education and Training. (2019). Report the situation of universities.

12. Minh, D. T. (2017). The marketization of public services provision in Vietnam. Hanoi: Knowledge.

13. Hai, P. T. T. (2018). University autonomy in the context of education innovation - a case study of Hanoi National University. Hanoi: Hanoi National University.

14. National Assembly of the Socialist Republic of Vietnam. (2018). The Law on Higher Education. 